\title{
Can viruses be modified to achieve sustained gene transfer
}

\author{
Hua Li and Hildegund C. J. ErtI* \\ Immunology Program, Wistar Institute, Philadelphia, PA, USA
}

Edited by:

Roland W. Herzog, University of

Florida, USA

Reviewed by:

George Q. Perrin, University of Florida, USA

Arun Srivastava, University of Florida USA

${ }^{*}$ Correspondence:

Hildegund C. J. Ertl, The Wistar

Institute, 3601 Spruce Street,

Philadelphia, PA 19104, USA.

e-mail: ert|@wistar.upenn.edu
It is very easy to replace a faulty gene in an immunocompromised mouse. First, one takes a well-characterized virus, such as an adenovirus or an adeno-associated virus, and incorporates the correct version of the faulty gene together with some regulatory sequences into the genome. Then, one transduces the recombinant genome into helper cells, which will add the viral capsid. At last, one injects the resulting viral vector into the sick mouse, and the mouse is cured. It is not that easy in an immunocompetent mouse, let alone in a human, as over the eons the immune system evolved to eliminate viruses regardless if they penetrate as dangerous pathogens or are injected by a well-meaning gene therapist. Here we offer our perspective on the potential of how viral vectors achieve sustained gene transfer in the face of a hostile immune system.

Keywords: gene therapy
Gene therapy, which aims to temporarily or permanently replace a faulty or missing protein at therapeutic levels, requires efficient transfer of genes into a host cell. The gene transfer vehicle has to withstand enzymes in blood, find the right cells, enter them and then their nucleus. Viruses meet these criteria to the dot; their capsids protect the genome, ensure that they enter cells and then facilitate transfer of the gene into the nucleus.

Gene therapists have been attempting to take advantage of viruses' talents for gene transfer focusing on viruses that commonly infect humans. During the milleniums, well before primates climbed down from trees evolution has selected for cellular organisms that can fight off viral infection first through primitive innate immune responses and then about 410 million years ago through an adaptive immune system and its high specificity and ability to remember. Living beings have thus evolved for billions of years to combat viruses. The evolution of gene therapy pales in comparison; the first humans were treated a mere 21 years ago.

Gene therapy can roughly be divided into two fields, transient and permanent gene therapy. The latter can be divided into $e x$ and in vivo therapy. Transient or ex vivo gene transfers have their own sets of problems, but the virtually insurmountable challenges caused by anti-viral immune responses are mainly faced upon direct injection of a viral vector for in vivo correction of a gene.

The two viral vectors most commonly used are based on adeno(Ad) and adeno-associated viruses (AAV).

Humans encounter different serotypes of Ad viruses early in life and develop neutralizing antibodies. Prevalence rates of such antibodies vary depending on the Ad serotype and the geographic region (Chen et al., 2010). Neutralizing antibodies prevent the virus from entering its target and thus reduce transduction rates. This can be overcome, e.g., by using alternative Ad serotypes. $\mathrm{CD}^{+} \mathrm{T}$ cells pose the bigger problem. Humans have robust numbers of Ad virus-specific $\mathrm{CD}^{+} \mathrm{T}$ cells (Chen et al., 2010), which are activated and are chock-full of granules containing lytic enzymes (Hutnick et al., 2010). Even immunosuppression, short of complete $\mathrm{T}$ cell ablation, would have no effect on the $\sim 1$ billion
Ad virus-specific $\mathrm{CD}^{+} \mathrm{T}$ cells of the average adult, which can commence lysis immediately.

In AAVs vectored for use in gene therapy, the ORFs are removed and replaced with the gene of interest flanked by the ITRs. Conversion of the ssDNA genome of AAV vectors into double-stranded (ds)DNA is rate limiting in transduction and delays onset of gene expression (Ferrari et al., 1996). DsAAV vectors have been developed and shown to achieve per vector genome copy higher levels of transgene product with accelerated onset of expression (McCarty et al., 2001; Nathwani et al., 2006).

Prevalence rates of neutralizing antibodies to the different AAV serotypes vary (Calcedo et al., 2009). Neutralizing antibodies, even if present at only low titers, readily blocks AAV-mediated gene transfer. Humans have circulating $\mathrm{CD}^{+}$and $\mathrm{CD}^{+}{ }^{+} \mathrm{T}$ cells to AAV capsid at low frequencies of approximately $0.1 \%$ of a given subset. They less activated than those to Ad viruses and belong predominantly to the effector memory or central memory subset (Li et al., 2011).

Adeno-associated viruses-mediated gene transfer readily results in sustained transgene expression in experimental animals (Song et al., 1998; Mount et al., 2002; Gao et al., 2006) presumably reflecting that AAV vectors are not particularly immunogenic. Based on successes in animals, AAV vectors were tested in clinical gene transfer trials. If given at moderate doses to an immunoprivileged site, they resulted in some correction of disease (Maguire et al., 2009). But if given systemically at the high doses needed to encode beneficial levels of a transgene product, such as factor (F) IX in hemophilia B, ssAAV vectors induced a capsid-specific $\mathrm{CD}^{+} \mathrm{T}$ cell response accompanied by loss of the therapeutic protein (Manno et al., 2006; Mingozzi et al., 2007). The potential success of AAV-mediated gene transfer in humans may turn out to be a numbers game. Transgene product expression by AAV vectors with a dsDNA genome is more efficient and in a recent trial a dsAAV8 vector achieved near therapeutic levels of factor FIX in hemophilia patients without evidence of $\mathrm{T}$ cell activation if given at a dose of $2 \times 10^{10} \mathrm{vg} / \mathrm{kg}$ (Nathwani, 2010). In a preceding trial 
with ssAAV2 vectors for FIX, doses of $8 \times 10^{10} \mathrm{vg} / \mathrm{kg}$ failed to elicit a $\mathrm{T}$ cell response but they also did not achieve detectable levels of FIX. At the next tested dose of $4 \times 10^{11} \mathrm{vg} / \mathrm{kg}$, T cell expansion was observed although levels of FIX still remained below detection. FIX levels together with increases in circulating AAV capsid-specific $\mathrm{T}$ cells were not observed till the final dose of $2 \times 10^{12} \mathrm{vg} / \mathrm{kg}$ (Manno et al., 2006; Mingozzi et al., 2007). The T cell response to the capsid proteins of AAV vectors is dictated by the input dose as without de novo synthesis of capsid proteins, $\mathrm{T}$ cells rely on presentation of degrading capsids, which are limiting both in terms of quantity and duration. Assuming that AAV vector doses below $\sim 10^{11} \mathrm{vg} / \mathrm{kg}$ can dodge recognition by $T$ cells, gene therapists should concentrate on the use of maximally efficient AAV vectors. Nevertheless, this assumption, which is based on low numbers of AAV vector

\section{REFERENCES}

Calcedo, R., Vandenberghe, L. H., Gao, G., Lin, J., and Wilson, J. M. (2009). Worldwide epidemiology of neutralizing antibodies to adenoassociated viruses. J. Infect. Dis. 199, 381-390.

Chen, H., Xiang, Z. Q., Li, Y., Kurupati, R. K., Jia, B., Bian, A., Zhou, D. M., Hutnick, N., Yuan, S., Gray, C., Serwanga, J., Auma, B., Kaleebu, P., Zhou, X., Betts, M. R., and Ertl, H. C. (2010). Adenovirus-based vaccines: comparison of vectors from three species of adenoviridae. J. Virol. 84, 10522-10532.

Ferrari, F. K., Samulski, T., Shenk, T., and Samulski, R. J. (1996). Secondstrand synthesis is a rate-limiting step for efficient transduction by recombinant adeno-associated virus vectors. J. Virol. 70, 3227-3234.

Gao, G. P., Lu, Y., Sun, X., Johnston, J., Calcedo, R., Grant, R., and Wilson, J. M. (2006). High-level transgene expression in nonhuman primate liver with novel adenoassociated virus serotypes containing self-complementary genomes. J. Virol. 80, 6192-6194.

Hutnick, N. A., Carnathan, D., Demers, K., Makedonas, G., Ertl, H. C., and Betts, M. R. (2010). Adenovirusspecific human $\mathrm{T}$ cells are pervasive, polyfunctional, and cross-reactive. Vaccine 28, 1932-1941.

Li, H., Lasaro, M. O., Jia, B., Lin, S. W., High, K. A., and Ertl, H. C. (2011).
Capsid-specific $\mathrm{T}$ cell responses to natural infections with adenoassociated viruses in humans differ from those of nonhuman primates. Mol. Ther. doi: 10.1038/mt.2011.81. [Epub ahead of print].

Maguire, A. M., High, K. A., Auricchio, A., Wright, J. F., Pierce, E. A., Testa, F., Mingozzi, F., Bennicelli, J. L., Ying, G. S., Rossi, S., Fulton, A., Marshall, K. A., Banfi, S., Chung, D. C., Morgan, J. I., Hauck, B., Zelenaia, O., Zhu, X., Raffini, L., Coppieters, F., De Baere, E., Shindler, K. S., Volpe, N. J., Surace, E. M., Acerra, C., Lyubarsky, A., Redmond, T. M., Stone, E., Sun, J., Mcdonnell, J. W., Leroy, B. P., Simonelli, F., and Bennett, J. (2009). Age-dependent effects of RPE65 gene therapy for Leber's congenital amaurosis: a phase 1 dose-escalation trial. Lancet 374, 1597-1605.

Manno, C. S., Pierce, G. F., Arruda, V. R., Glader, B., Ragni, M., Rasko, J. J., Ozelo, M. C., Hoots, K., Blatt, P., Konkle, B., Dake, M., Kaye, R., Razavi, M., Zajko, A., Zehnder, J., Rustagi, P. K., Nakai, H., Chew, A., Leonard, D., Wright, J. F., Lessard, R. R., Sommer, J. M., Tigges, M., Sabatino, D., Luk, A., Jiang, H., Mingozzi, F., Couto, L., Ertl, H. C., High, K. A., and Kay, M. A. (2006). Successful transduction of liver in hemophilia by AAV-Factor IX and limitations imposed by the host immune response. Nat. Med. 12, 342-347.

treated patients, has to be viewed with caution. Different serotypes of AAV vectors or even ss versus dsAAV vectors may differ in the degradation rate of their capsids. Processing of capsid for presentation of peptides with MHC class I molecules is mediated by proteases, which in turn are upregulated by proinflammatory cytokines. Capsids that are processed more rapidly may result in a bolus of epitopes, which may favor $\mathrm{T}$ cell recognition unlike capsids that are degraded slowly. Frequencies of circulating AAV capsid-specific $\mathrm{CD}^{+} \mathrm{T}$ cells in humans vary and humans with higher frequencies might be more prone to mount effective recall responses to AAV gene transfer than humans with low frequencies. Recommending firm doses for AAV-mediated gene transfer will thus not be feasible till larger cohorts have been tested and one can at this stage only advise a very conservative dose escalation.

McCarty, D. M., Monahan, P. E. and Samulski, R. J. (2001). Selfcomplementary recombinant adeno-associated virus (scAAV) vectors promote efficient transduction independently of DNA synthesis. Gene Ther. 8, 1248-1254.

Mingozzi, F., Maus, M. V., Hui, D. J., Sabatino, D. E., Murphy, S. L., Rasko, J. E., Ragni, M. V., Manno, C. S., Sommer, J., Jiang, H., Pierce, G. F., Ertl, H. C., and High, K. A. (2007). CD8(+) T-cell responses to adeno-associated virus capsid in humans. Nat. Med. 13, 419-422.

Mount, J. D., Herzog, R. W., Tillson, D. M., Goodman, S. A., Robinson, N., Mccleland, M. L., Bellinger, D., Nichols, T. C., Arruda, V. R., Lothrop, C. D. Jr., and High, K. A. (2002). Sustained phenotypic correction of hemophilia $\mathrm{B}$ dogs with a factor IX null mutation by liverdirected gene therapy. Blood 99, 2670-2676.

Nathwani, A. C. (2010). Haemophilia B gene therapy study in the UK. Paper Presented at Hemophilia 2010 World Congress LB01, Buenos Aires.

Nathwani, A. C., Gray, J. T., Ng, C. Y., Zhou, J., Spence, Y., Waddington, S. N., Tuddenham, E. G., KemballCook, G., Mcintosh, J., Boon-Spijker, M., Mertens, K., and Davidoff, A. M. (2006). Self-complementary adenoassociated virus vectors containing a novel liver-specific human factor
IX expression cassette enable highly efficient transduction of murine and nonhuman primate liver. Blood 107 2653-2661.

Song, S., Morgan, M., Ellis, T., Poirier, A., Chesnut, K., Wang, J., Brantly, M., Muzyczka, N., Byrne, B. J., Atkinson, M., and Flotte, T. R. (1998). Sustained secretion of human alpha1-antitrypsin from murine muscle transduced with adeno-associated virus vectors. Proc. Natl. Acad. Sci. U.S.A. 95, 14384-14388.

Conflict of Interest Statement: The authors declare that the research was conducted in the absence of any commercial or financial relationships that could be construed as a potential conflict of interest.

Received: 26 April 2011; accepted: 28 June 2011; published online: 12 July 2011.

Citation: Li H and Ertl HCJ (2011) Can viruses be modified to achieve sustained gene transfer. Front. Microbio. 2:152. doi: 10.3389/fmicb.2011.00152

This article was submitted to Frontiers in Microbial Immunology, a specialty of Frontiers in Microbiology.

Copyright (c) $2011 \mathrm{Li}$ and Ertl. This is an open-access article subject to a nonexclusive license between the authors and Frontiers Media SA, which permits use, distribution and reproduction in other forums, provided the original authors and source are credited and other Frontiers conditions are complied with. 